\title{
SKRINING FITOKIMIA DAN UJI KEMAMPUAN SEBAGAI ANTIOKSIDAN DARI DAUN JAMBU BIJI (Psidium guajava. L)
}

\author{
Tri Bintarti \\ Jurusan Farmasi Politeknik Kesehatan Medan
}

\begin{abstract}
Abstrak
Radikal bebas merupakan molekul yang mempunyai elektron bebas, sangat mengganggu kesehatan. Salah satu upaya penanggulangannya dengan antioksidan. Berbagai antioksidan sintetis telah digunakan misalnya butilhidroksi toluen dan butilhidroksi anisol, namun menimbulkan efek samping yang merugikan kesehatan. Secara alamiah di dalam tubuh terdapat antioksidan yaitu superoksida dismutase, glutatin dan katalase, tetapi tergantung pada asupan makanan terutama mengandung fenolik dan flavonoid. Secara trdisional daun jambu biji digunakan untuk mengobati diare, disentri, menurunkan kolesterol, haid tidak teratur, luka, dan sariawan. Dilihat dari berbagai khasiat ini kemungkinan daun jambu biji mengandung senyawa kimia yang berpotensial sebagai antioksidan, terutama senyawa fenolik, maka penulis menguji kemampuan daun jambu biji sebagai antioksidan. Daun jambu biji disiapkan menjadi ekstrak etanol, difraksinasi dengan n-heksan, etil asetat dan air, dilakukan skrining fitokimia terhadap ekstrak etanol dan masing-masing fraksi. Pengujian antioksidan dilakukan dengan metode Radical Scavenger menggunakan 1,1-diphenyl-2-picrylhydrazyl. Hasil pengujian menunjukkan ekstrak etanol mengandung alkaloid, tannin, flavonoi, steroid, saponin, dan glikosida. fraksi n-heksan mengandung alkaloid dan glikosida. fraksi etil asetat mengandung tanin. fraksi air mengandung tannin dan glikosida. Sebagai antioksidan ekstrak etanol dan fraksi air berkategori kuat dengan $\mathrm{IC}_{50}$ etanol $=42,06 \mu \mathrm{g} / \mathrm{ml}$, fraksi air $=49,41 \mu \mathrm{g} / \mathrm{ml}$, fraksi n-heksan dan etil asetat berkategori sedang dengan $\mathrm{IC}_{50}$ fraksi n-heksan $=58,15 \mu \mathrm{g} / \mathrm{ml}$, fraksi etil asetat $=51,60 \mu \mathrm{g} / \mathrm{ml}$.
\end{abstract}

Kata kunci: Daun jambu biji, antioksidan, Radical Scavenger, 1,1-diphenyl-2-picrylhydrazyl

\section{PENDAHULUAN}

Di berbagai media massa, telah banyak diungkapkan bahaya-bahaya yang timbul akibat asupan makanan dan lingkungan yang tidak sehat karena adanya pembentukan radikal bebas. Hal ini terutama dialami oleh masyarakat di perkotaan yang mempunyai banyak kesibukan cenderung memilih makanan instant yang mudah persiapannya banyak mengandung bahan tambahan makanan yang mengandung radikal bebas, dan polusi udara yang juga mengandung radikal bebas (Safitri, 2002).

Radikal bebas merupakan suatu molekul, atom, atau grup beberapa atom yang memiliki elektron yang tidak berpasangan akan menarik elektron dari senyawa lain di sekitarnya, misalnya dari protein, lipid, karbohidrat, dan DNA (deoxyribo nucleat acid), yaitu senyawa yang terdapat dalam inti sel, sehingga sel-sel ini akan mengalami kerusakan yang akhirnya akan menyebabkan berbagai macam penyakit, di antaranya penyakit kanker, katarak, diabetes mellitus, ginjal, asma, gangguan paru, hati dan radang usus (Kumalaningsih, 2006).

Salah satu upaya penaggulangan bahaya radikal bebas adalah dengan cara pemberian antioksidan. Antioksidan merupakan suatu atom, molekul, atau senyawa kimia yang dapat memberikan elektron kepada molekul radikal bebas sehingga memutuskan reaksi berantai dari radikal bebas, sehingga menghambat laju reaksi oksidasi dengan cara bereaksi dengan radikal bebas reaktif lalu membentuk suatu senyawa tidak reaktif dan relatif stabil (Sofia, 2005).

Senyawa antioksidan sintesis yang cukup dikenal adalah butilhidroksitoluen (BHT) dan butilhidroksianisol (BHA). Kedua senyawa antioksidan ini banyak dimanfaatkan dalam industri makanan dan minuman. Namun, beberapa hasil penelitian telah membuktikan bahwa ke dua antioksidan tersebut mempunyai efek samping yang tidak diinginkan, yaitu berpotensi sebagai karsinogenik terhadap reproduksi dan metabolisme. Berdasarkan uji toksisitas akut dan kronik pada hewan percobaan, pemakaian zat antioksidan ini maksimal dalam campuran makanan adalah 200 ppm (Hernani, 2004).

Secara alamiah di dalam tubuh kita terdapat senyawa bersifat antioksidan yang berperan aktif dalam menanggulangi masalah radikal bebas yaitu adanya enzim superoksida dismutase atau SOD, glutatin dan katalase dapat melindungi sel-sel dari serangan radikal bebas. Namun hal ini tergantung pada pola hidup dan pola makan atau asupan makanan yang banyak mengandung vitamin $\mathrm{C}$, vitamin $\mathrm{E}$, senyawa betakaroten, fenolik dan flavonoid. Tumbuh-tumbuhan merupakan sumber utama antioksidan karena di dalam daun, bunga, buah, biji-bijian banyak mengandung senyawa kimia yang mempunyai aktifitas sebaga antioksidan yaitu tokoferol, asam askorbat, karotenid, senyawa polifenol dan flavonoid. (Anonim, 2001), contohnya adalah daun jambu biji (Psidium guajava L.) karena secara tradisional telah terbukti dapat mengobati 
berbagai penyakit yaitu diare akut dan kronis, disentri, perut kembung pada bayi dan anak, kadar kolesterol darah meninggi, haid tidak teratur, sering buang air kecil (anyang-anyangan), luka, dan sariawan. Dilihat dari berbagai khasiat ini besar kemungkinan daun jambu biji mengandung berbagai bahan kimia terutama yang mempunyai gugus fenolik yang sangat berpotensial sebagai antioksidan (Dalimartha 2006).

Sebuah metode yang cepat, sederhana dan mudah untuk mengukur aktifitas antioksidan adalah dengan metode peredaman radikal bebas (Radical Scavenger) menggunakan 1,1-diphenyl-2-picrylhydrazyl (DPPH) sebagai radikal bebas. Metode ini telah digunakan luas untuk menguji kemampuan sebagai antioksidan dari suatu senyawa atau komponen dari berbagai sampel berbentuk padat atau cair (Darmawan, 2004).

Berdasarkan hal di atas maka peneliti tertarik untuk melakukan skrining fitokimia dan pengujian aktivitas antioksidan dari ekstrak etanol dan fraksi n-heksan, etil asetat, dan air dari daun jambu biji (Psidium guajava L.). Pengujian antioksidan dilakukan dengan metode peredaman radikal bebas (Radical Scavenger) menggunakan 1,1-diphenyl-2-picrylhydrazyl (DPPH).

\section{TINJAUAN PUSTAKA}

\subsection{Antioksidan}

Jika di suatu tempat terjadi reaksi oksidasi dan reaksi tersebut menghasilkan hasil samping berupa radikal bebas, selanjutnya radikal bebas yang terbentuk ini akan menyerang molekul-molekul lain di sekitarnya. Hasil reaksi ini akan dapat menghasilkan radikal bebas lain yang siap menyerang molekul yang lainnya lagi. Akhirnya akan terbentuk reaksi berantai yang sangat membahayakan. Tetapi bila terdapat antioksidan, radikal bebas akan segera bereaksi dengan antioksidan membentuk molekul yang stabil dan reaksinya terhenti.

Setiap sel mempunyai sistem defensif antioksidan enzimatis berupa perangkat yang dapat menagkal radikal bebas secara alami seperti glutation perokside (GSH.Prx), ubikuinol, katalase, superokside dismutase (SOD), hydroperokside dan lain sebagainya. Enzim SOD akan menjinakkan senyawa oksigen reaktif seperti superokside anion (O-2) akan merubah radikal menjadi $\mathrm{H} 2 \mathrm{O} 2$, selanjutnya GSH.Prx mengubahnya menjadi air (H2O) dan dikeluarkan dari tubuh. Namun dengan meningkatnya usia terjadilah penurunan enzim ini dalam tubuh sehinga radikal bebas tidak sepenuhnya dapat dimusnahkan, apalagi dengan banyaknya pemasukan radikal bebas dari luar tubuh, semakin sulit tubuh menghancurkan radikal bebas ini.

Selain jenis antioksidan enzimatis, juga dikenal jenis antioksidan non enzimatis. Jenis ini dapat berupa golongan vitamin seperti vitamin $\mathrm{C}$, A, dan $\mathrm{E}$, golongan mineral seperti selenium dan seng serta golongan senyawa senyawa fenolik, flavonoid dan karotenoid (betakaroten, likopen, lutein) dan yang khusus dari hewan yaitu astaxanthin. (Saurisari, 2006).

Antioksidan sintetik yaitu yang dibuat dari bahan-bahan kimia secara sintetis, antara lain: butyl hidroksi anisol (BHA), butyl hidroksi toluene (BHT), terbutil hidroksi quinon (TBHQ), propil galat (PG) dan nordihidroguairatic acid (NDGA).

\subsubsection{Penentuan aktifitas antioksidan}

Bermacam-macam metode telah digunakan untuk memantau dan membandingkan aktifitas antioksidan pada makanan. Pada beberapa tahun belakangan ini, pengujian absorbansi oksigen radikal telah digunakan untuk mengevaluasi aktifitas antioksidan pada makanan, serum dan cairan biologi lain. Metode analisa ini mengukur aktifitas dari antioksidan dalam melawan radikal bebas seperti 1,1-diphenyl-2-picrylhydrazyl (DPPH) radikal, anion superoksida radikal (O2), hidroksiradikal (OH) atau peroksiradikal (ROO). (Darmawan, 2004).

Sebuah metode yang cepat, sederhana dan mudah untuk mengukur kapasitas antioksidan dari makanan menggunakan radikal bebas 1,1-diphenyl-2-picrylhydrazyl (DPPH). DPPH berwarna ungu menyerap kuat pada panjang gelombang $515 \mathrm{~nm}$. digunakan luas untuk menguji kemampuan aktifitas antioksidan dari makanan, dapat digunakan untuk sampel padat atau cair (Darmawan, 2004).

\subsection{Radikal Bebas}

Radikal bebas merupakan atom atau molekul yang sifatnya sangat tidak stabil. Ketidakstabilan ini disebabkan karena atom tersebut memiliki satu atau lebih elektron yang tidak berpasangan. Atom tersebut berusaha untuk memiliki pasangan elektron, sehingga sifatnya sangat reaktif. Atom ini cenderung mencari partikel dari molekul lain dan kemudian membuat senyawa baru yan tidak normal. Partikel atau elektron yang dijadikan pasangan baru itu bisa diambil dari DNA, membran/selaput sel, membran lisosom (bagian sel yang mengandung enzim hidrolitik), mitokondria (tempat produksi energi sel), enzim-enzim, lemak, protein serta komponen jaringan lain (Kosasih, 2005).

Pembentukan radikal bebas dan reaksi oksidasi pada biomolekul akan berlangsung sepanjang hidup. Inilah peyebab utama dari proses penuaan sel dan berbagai penyakit degenerative seperti strok, asma, gangguan paru, hati, ginjal, diabetes militus, radang usus, penyumbatan kronis pembuluh darah jantung (jantung koroner), nerogeneratif seperti parkinson dan dementia/pikun, bahkan radikal bebas dapat juga menyebabkan AIDS. Radikal bebas yang sangat berbahaya antara lain adalah golongan hidroksil $(\mathrm{OH})$, superoksida $(\mathrm{O} 2)$, nitrogen monoksida peroksida (NO) dan peroksil (RO2). Sedangkan golongan yang bukan radikal tetapi dengan mudah dapat menjurus ke reaksi-reaksi radikal bebas antara lain adalah peroksinitrit (ONOO), asam hipoklorit ( $\mathrm{HOCl})$ dan hidrogenperoksida (H2O2) (Silalahi, 2006).

Radikal bebas bisa berasal dari dalam tubuh kita sendiri maupun lingkungan. Di dalam tubuh, setiap proses sel normal yang melibatkan oksigen misalnya pernafasan atau pencernaan akan menghasilkan radikal bebas, maka radikal bebas dapat berasal dari endogen maupun eksogen yang terjadi melalui sederetan mekanisme reaksi, yaitu pertama pembentukan awal radikal bebas (inisiasi), lalu 
perambatan atau terbentuknya radikal baru (propagasi) dan tahap terakhir (terminasi) adalah pemusnahan atau pengubahan menjadi senyawa stabil dan tak reaktif (Saurisari, 2006).

Radikal bebas ini dapat diatasi dengan cara mencegah masukknya radikal

bebas ke dalam tubuh misalnya menghindari paparan dengan sinar UVB berlebihan yaitu menggunakan tabir surya, mengatur pola makan yang baik (tidak berlebihan), menghindari komsumsi bahan tambahan makanan seperti bahan pengawet, pewarna, pemanis buatan, menghindari dari stres, rokok, minum beralkohol, polusi udara dan juga menjaga agar tidak melakukan olahraga berlebihan. Disamping itu dengan menggunakan antioksidan (Kosasih, 2005).

\section{METODE PENELITIAN}

\subsection{Bahan -bahan dan Alat-alat}

\subsubsection{Bahan -bahan}

Bahan kimia yang digunakan berkualitas proanalisa (p.a) kecuali dinyatakan lain adalah produksi EMerck yaitu : asam sulfat pekat, asam klorida pekat, etil asetat, besi (III) klorida, metanol, natrium hidroksida, serbuk magnesium, serbuk seng, netanol, n-heksana, etil asetat, dan berkualitas pro analisa produksi Sigma: 1.1diphenyl-2-pycrylhydrazyl (DPPH), air suling (Laboratorium Kesehatan Daerah Medan).

\subsubsection{Alat-alat}

Alat-alat yang digunakan adalah alat-alat gelas laboratorium, blender (National), freeze dryer (Modulyo, Edward, serial No.398), neraca kasar (Ohaus), neraca listrik (Vibra), spektrofotometer visibel (Shimadzu).

\subsection{Tahapan kerja :}

Tahapan kerja yang dilakukan : pengumpulan, dan pengolahan sampel, pembuatan ekstrak dengan cara perkolasi diikuti dengan fraksinasi menggunakan n-heksan + air dan etil asetat, identifikasi senyawa kimia golongan alkaloid, flavanoid, glikosida, tannin, saponin, steroid/triterpenoid dari ekstrak etanol, fraksi n-heksan, fraksi rtil asetat, dan fraksi air, serta pengujian aktifitas antioksidan dengan metode Radical Scavenger,

\subsection{Pengujian Aktifitas Antioksidan}

\subsubsection{Penetapan panjang gelombang}

Disiapkan larutan konsentrasi $40 \mu \mathrm{g} / \mathrm{ml}$, lalu diukur absorbansinya pada panjang gelombang 400-800 $\mathrm{nm}$, sehingga diperoleh absorbansi maksimum sebagai panjang gelombang.

\subsubsection{Pengukuran absorbansi DPPH tanpa sampel (blanko)}

Larutan DPPH konsentrasi $40 \mu \mathrm{g} / \mathrm{ml}$, diukur absorbansinya dengan spektrofotometer visible pada panjang gelombang $516 \mathrm{~nm}$ dengan selang waktu 5 menit sampai 30 menit sehingga diperoleh berbagai harga absorbansi.

\subsubsection{Pengukuran absorbansi DPPH setelah penambahan sampel \\ Disiapkan larutan uji (ekstrak etanol daun jambu} biji dan hasil fraksinya dengan berbagai bahan penyari) masing-masing konsentrasi $4 \mu \mathrm{g} / \mathrm{ml}, 8 \mu \mathrm{g} / \mathrm{ml}, 12 \mu \mathrm{g} / \mathrm{ml}$ dan $16 \mu \mathrm{g} / \mathrm{ml}$ di labu tentukur $25 \mathrm{ml}$. ditambahkan $4 \mathrm{ml}$ larutan DPPH (1.1-diphenyl-2-picrylhydrazyl) $40 \mu \mathrm{g} / \mathrm{ml}$, lalu volumenya dicukupkan dengan metanol hingga garis tanda. Kemudian diukur absorbansinya dengan spektrofotometer visible pada panjang gelombang $516 \mathrm{~nm}$ mulai dari 5 menit setelah penambahan DPPH dengan interval waktu 5 menit sampai 30 menit. Kemampuan bahan uji sebagai antioksidan dihitung berdasakan penurunan serapan larutan DPPH akibat adanya penambahan bahan uji. Nilai serapan larutan DPPH sebelum dan sesudah penambahan bahan uji dihitung sebagi persen inhibisi (\% inhibisi) dengan rumus sebagai

berikut : $\%$ inhibisi $=\frac{A_{\text {kontrol }}-A_{\text {sampel }}}{A_{\text {kontrol }}} \times 100$

Keterangan :

$\mathrm{A}_{\text {kontrol }}=$ Absorbansi DPPH tidak mengandung sampel.

$\mathrm{A}_{\text {sampel }}=$ Absorbansi DPPH mengandung sampel.

Selanjutnya dilakukan perhitungan persamaan garis regresi dengan konsentrasi sampel $(\mu \mathrm{g} / \mathrm{ml})$ sebagai absis (sumbu X) dan nilai inhibisi sebagai ordinatnya (sumbu Y). selanjutnya kemampuan bahan uji sebagai antioksidan dengan diperhitungkan dengan harga Inhibitor Concentration 50\% (IC50) menggunakan rumus :

$$
50=a x+b
$$

Keterangan : $a=$ Absortifitas

$\mathrm{b}=$ Tebal kuvet

$\mathrm{x}=$ Konsentrasi

\section{HASIL PENELITIAN}

\subsection{Hasil Skrining Fitokimia}

Hasil Skrining fitokimia ditunjukkan pada Tabel 1: Tabel 1 : Hasil skrining fitokimia kimia

\begin{tabular}{|c|c|c|c|c|c|c|c|}
\hline & & $\begin{array}{c}\text { Alkaloi } \\
\text { da }\end{array}$ & Tanin & $\begin{array}{c}\text { Flavonoi } \\
\mathrm{da}\end{array}$ & $\begin{array}{l}\text { Steroida/ } \\
\text { riterpenoid }\end{array}$ & Saponin & $\begin{array}{c}\text { Glikosi } \\
\mathrm{da}\end{array}$ \\
\hline 1 & Daun segar & $(+)$ & $(+)$ & $(+)$ & $(+)$ & $(+)$ & $(+)$ \\
\hline 2 & Simplisia kering & $(+)$ & $(+)$ & $(+)$ & $(+)$ & $(+)$ & $(+)$ \\
\hline 3 & Ekstrak Etanol & $(+)$ & $(+)$ & $(+)$ & $(+)$ & $(+)$ & $(+)$ \\
\hline 4 & Fraksin-Heksan & $(+)$ & $(-)$ & $(-)$ & $(+)$ & $(-)$ & $(+)$ \\
\hline 5 & Fraksi Etil Asetat & $(+)$ & $(+)$ & $(-)$ & $(+)$ & $(-)$ & $(-)$ \\
\hline 6 & Fraksi Air & $(-)$ & $(+)$ & $(-)$ & $(-)$ & $(-)$ & $(+)$ \\
\hline
\end{tabular}

\subsection{Hasil Uji Aktifitas Antioksidan}

Hasil pengukuran absorbansi rata-rata dari ekstrak etanol dan fraksinasi dengan berbagai penyari daun jambu biji ditunjukkan pada Tabel 2 dan Gambar 1: 
Tabel 2. Absorbansi dari ekstrak etanol dan berbagai fraksi daun jambu biji

\begin{tabular}{|c|c|c|c|c|c|c|c|c|}
\hline \multirow{2}{*}{ No } & \multirow{2}{*}{$\begin{array}{c}\text { Ekstrak/ } \\
\text { fraksi }\end{array}$} & \multirow{2}{*}{$\begin{array}{c}\text { Konsentrasi } \\
(\mu \mathrm{g} / \mathrm{ml}) \\
\end{array}$} & \multicolumn{6}{|c|}{ Absorbansi blanko dan bahan uji dengan berbagai konsentrasi } \\
\hline & & & 5 menit & 10 menit & 15 menit & 20 menit & 25 menit & 30 menit \\
\hline & & Blanko & 0.7294 & 0.7325 & 0.7339 & 0.7357 & 0.7377 & 0.74 \\
\hline \multirow[t]{4}{*}{1} & \multirow{4}{*}{$\begin{array}{l}\text { Ekstrak } \\
\text { etanol }\end{array}$} & 4 & 0.6326 & 0.6316 & 0.6306 & 0.6295 & 0.6285 & 0.6274 \\
\hline & & 8 & 0.618 & 0.6167 & 0.6157 & 0.6147 & 0.6139 & 0.6129 \\
\hline & & 12 & 0.6095 & 0.6088 & 0.6081 & 0.6073 & 0.6065 & 0.6055 \\
\hline & & 16 & 0.7294 & 0.7325 & 0.7339 & 0.7357 & 0.7377 & 0.74 \\
\hline \multirow{4}{*}{2} & Fraksi & 4 & 0.6626 & 0.6616 & 0.6606 & 0.6595 & 0.6585 & 0.6574 \\
\hline & n-heksan & 8 & 0.648 & 0.6467 & 0.6457 & 0.6447 & 0.6439 & 0.6429 \\
\hline & & 12 & 0.6395 & 0.6388 & 0.6381 & 0.6373 & 0.6365 & 0.6355 \\
\hline & & 16 & 0.6285 & 0.6278 & 0.6271 & 0.6264 & 0.6255 & 0.6247 \\
\hline \multirow[t]{4}{*}{3} & Fraksi & 4 & 0.6576 & 0.6566 & 0.6556 & 0.6545 & 0.6535 & 0.6524 \\
\hline & etil asetat & 8 & 0.643 & 0.6417 & 0.6407 & 0.6397 & 0.6389 & 0.6379 \\
\hline & & 12 & 0.6345 & 0.6338 & 0.6331 & 0.6323 & 0.6315 & 0.6305 \\
\hline & & 16 & 0.6235 & 0.6228 & 0.6221 & 0.6214 & 0.6205 & 0.6197 \\
\hline \multirow[t]{4}{*}{4} & \multirow[t]{4}{*}{ Fraksi air } & 4 & 0.6526 & 0.6516 & 0.6506 & 0.6495 & 0.6485 & 0.6474 \\
\hline & & 8 & 0.638 & 0.6367 & 0.6357 & 0.6347 & 0.6339 & 0.6329 \\
\hline & & 12 & 0.6295 & 0.6288 & 0.6281 & 0.6273 & 0.6265 & 0.6255 \\
\hline & & 16 & 0.6185 & 0.6178 & 0.6171 & 0.6164 & 0.6155 & 0.6147 \\
\hline
\end{tabular}

\section{PEMBAHASAN}

Hasil skrining fitokimia menunjukkan bahwa ekstrak etanol, mengandung alkaloid, tannin, flavonoida, steroida, saponin, dan glikosida, berarti sangat berpotensial sebagai antioksidan Fraksi n-heksan tidak positif adanya tanin dan flvonoid, namun masih ada kemungkinan mempunyai aktifitas sebagai antioksidan karena kemungkinan pada golongan alkaloid dan glikosida mempunyai gugus fenol walaupun tidak sebesar senyawa polifenol seperti tannin dan flavonoid. Fraksi etil asetat, dan fraksi air mengandung senyawa tanin, yang berpotensial sebagai antioksidan, selain itu pada fraksi air terlihat adanya glikosida, juga kemungkinan mempunyai aktifitas antioksidan

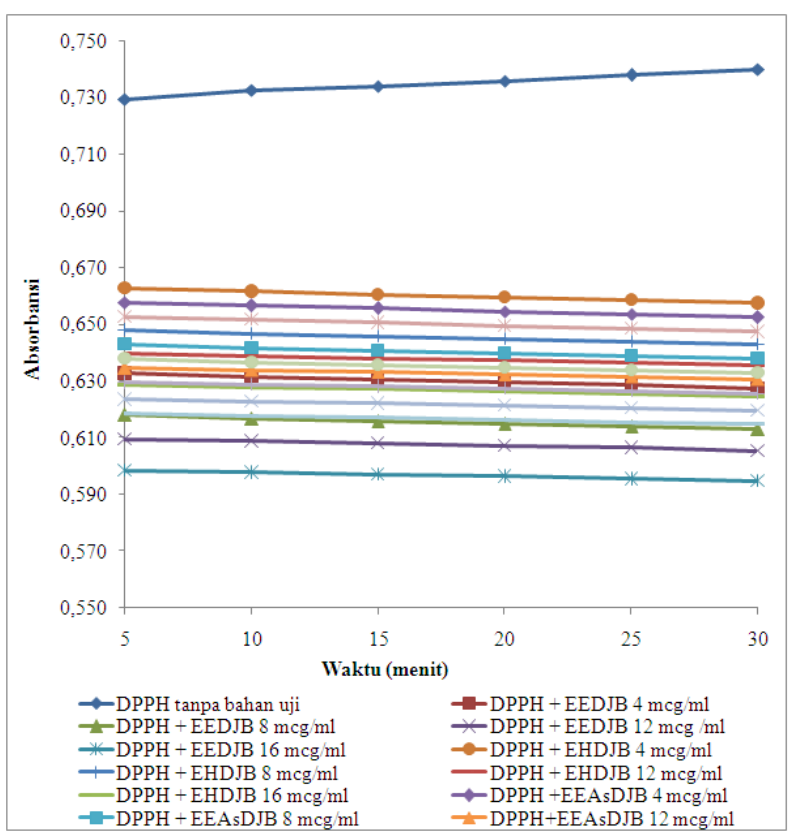

Tabel 2 dan Gambar1 menunjukkan terjadinya penurunan absorbansi dari DPPH yang telah ditambah bahan uji, semakin besar konsentrasi bahan uji yang ditambahkan dan semakin lama waktu waktu pengukuran, penurunan absorbansi-nya semakin besar, sedangkan pada DPPH sendiri tanpa penambahan bahan uji sampai 30 menit pengukuran absorbansi-nya semakin bertambah, terlihat perbedaan laju penurunan absorbansi pada setiap bahan uji. Ini dapat dihubungkan dengan hasil pengujian skrining fitokimia terdapat perbedaan golongan senyawa yang terkandung di dalam masing-masing ekstrak dan fraksi, walaupun secara pasti jenis senyawa kimia apa saja yang mempunyai aktifitas sebagai antioksidan yang terkaandung di dalam daun jambu biji ini belum diketahui secara pasti. Selanjutnya untuk mengetahui berapa besar kemampuan aktifitas dari setiap bahan uji sebagai antioksidan dapat dilakukan dengan perhitungan harga IC50 Hasilnya dapat dilihat pada Tabel 3 dan Gambar 2.

Tabel 3. Persen inhibisi dan hasil perhitungan harga IC50

\begin{tabular}{|c|c|c|c|c|c|c|c|c|}
\hline \multirow{2}{*}{$\begin{array}{l}\text { Ekstrak/ } \\
\text { fraksi }\end{array}$} & \multirow{2}{*}{$\begin{array}{c}\text { Konsen } \\
\text { trasi } \\
(\mu \mathrm{g} / \mathrm{ml})\end{array}$} & \multicolumn{6}{|c|}{ Persen inhibisi dari bahan uji dengan berbagai konsentrasi } & \multirow{2}{*}{ IC 50} \\
\hline & & 5 menit & 10 menit & 15 menit & 20 menit & 25 menit & 30 menit & \\
\hline \multirow{4}{*}{$\begin{array}{l}\text { Ekstrak } \\
\text { etanol }\end{array}$} & 4 & 13.27 & 13.77 & 14.08 & 14.44 & 14.81 & 15.21 & \multirow[t]{4}{*}{42,06} \\
\hline & 8 & 15.27 & 15.81 & 16.11 & 16.79 & 16.79 & 17.17 & \\
\hline & 12 & 16.44 & 16.89 & 17.15 & 17.46 & 17.8 & 18.18 & \\
\hline & 16 & 17.95 & 18.38 & 18.64 & 18.94 & 19.28 & 19.63 & \\
\hline Fraksi & 4 & 8.06 & 8.58 & 8.9 & 9.27 & 9.66 & 10.08 & \multirow[t]{4}{*}{58,15} \\
\hline \multirow[t]{3}{*}{ n-heksan } & 8 & 10.06 & 10.62 & 10.93 & 11.64 & 11.64 & 12.04 & \\
\hline & 12 & 11.23 & 11.7 & 11.97 & 12.29 & 12.64 & 13.04 & \\
\hline & 16 & 12.74 & 13.2 & 13.47 & 13.77 & 14.13 & 14.5 & \\
\hline Fraksi & 4 & 9.84 & 10.36 & 10.67 & 11.04 & 11.42 & 11.83 & \multirow[t]{4}{*}{51,60} \\
\hline \multirow[t]{3}{*}{ etil asetat } & 8 & 11.84 & 12.4 & 12.7 & 13.4 & 13.4 & 13.79 & \\
\hline & 12 & 13.01 & 13.47 & 13.74 & 14.06 & 14.41 & 14.8 & \\
\hline & 16 & 14.52 & 14.97 & 15.24 & 15.54 & 15.89 & 16.25 & \\
\hline \multirow{4}{*}{ Fraksi air } & 4 & 10.53 & 11.04 & 11.35 & 11.72 & 12.1 & 12.51 & \multirow[b]{4}{*}{49,41} \\
\hline & 8 & 12.53 & 13.08 & 13.38 & 14.08 & 14.08 & 14.47 & \\
\hline & 12 & 13.7 & 14.15 & 14.42 & 14.74 & 15.08 & 15.48 & \\
\hline & 16 & 15.2 & 15.65 & 15.92 & 16.22 & 16.57 & 16.93 & \\
\hline
\end{tabular}

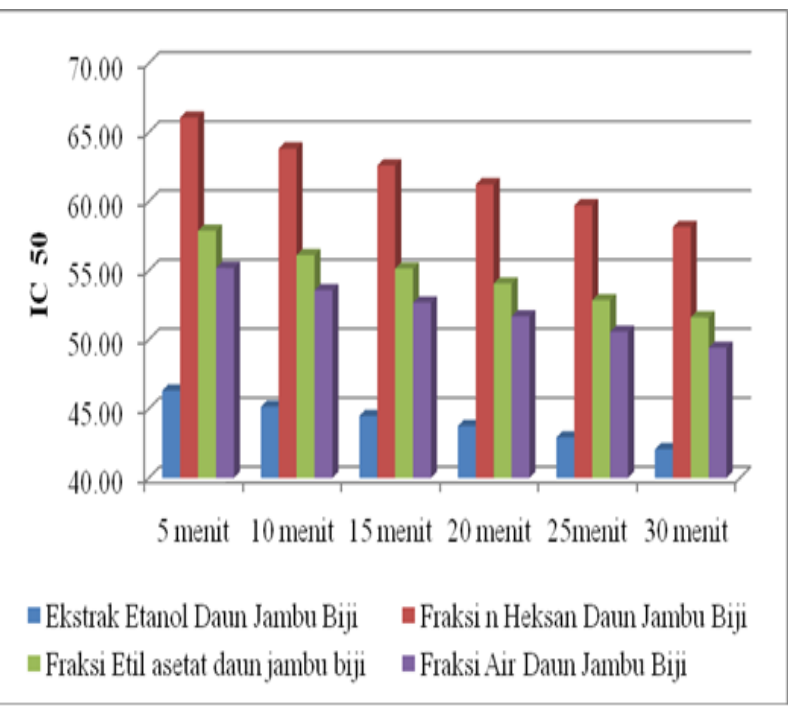

Gambar 2. Histogram harga IC 50 dari ekstrak etanol dan berbagai fraksi daun jambu biji 
Secara spesifik, suatu senyawa dikatakan sebagai antioksidan sangat kuat jika nilai IC50 kurang dari $50 \mu \mathrm{g} / \mathrm{ml}$, kuat jika IC50 bernilai $50-100 \mu \mathrm{g} / \mathrm{ml}$, sedang jika IC50 bernilai $100-150 \mu \mathrm{g} / \mathrm{ml}$ dan lemah jika IC50 151-200 $\mu \mathrm{g} / \mathrm{ml}$ (Anonim, 2005) Tabel 4.5 dan Gambar 11 menunjukkan bahwa pada pengukuran sampai dengan waktu 30 menit kemampuan antioksidan ekstrak etanol berkategori kuat memiliki nilai $\mathrm{IC50}=42,06 \mu \mathrm{g} / \mathrm{ml}$, fraksi n-heksan berkategori sedang memiliki IC50 $=58,15 \mu \mathrm{g} / \mathrm{ml}$, fraksi etil asetat berkategori sedang memiliki $51,60 \mu \mathrm{g} / \mathrm{ml}$, dan fraksi air berkategori kuat memiliki IC50 $=49,41 \mu \mathrm{g} / \mathrm{ml}$. Ini menunjukkan bahwa daun jambu biji mempunyai kemampuan yang baik sebagai antioksidan, dan yang paling kuat adalah ekstrak etanol.

\section{KESIMPULAN}

Berdasarkan hasil penelitian pengujian skrining fitokimia terhadap ekstrak etanol, fraksi n-heksan, fraksi etil asetat, dai fraksi air dari daun jambu biji (Psidium guajava L.) dan uji kemampuannya sebagai antioksidan dapat disimpulkan sebagai berikut :

1. Hasil skrining fitokimia menunjukkan ekstrak etanol mengandung alkaloid, tannin, flavonoid, steroid, saponin, dan glikosida. Fraksi n-heksan mengandung golongan alkaloida dan glikosida. Fraksi etil asetat mengandung senyawa tanin. Fraksi air mengandung tannin dan glikosida.

3. Ekstrak etanol dan fraksi air daun jambu biji mempunyai aktifitas antioksidan berkategori kuat, pada fraksi n-heksan dan etil asetat mempunyai antioksidan berkategori sedang.

\section{DAFTAR PUSTAKA}

Anonim. Antioxidan Activity of Five Vegetable Traditioinally Consumed by South-Asian Migrants in Bradford, Yorkshire. UK. Online 2001. http://www.interscience.wiley.co.uk/health/chartshtml

Day, R.A. dan Underwood, A.L. (1986). Analisis Kimia Kuantitatif, Edisi Ke-6. Terjemahan Iis Sopyan. Jakarta. Erlangga. Hal 382.

Departemen Kesehatan RI. (1989). Materia Medika Indonesia, Jilid V. Jakarta: Depkes RI. Hal 513, 526, 536, 540, 549.

Departemen Kesehatan RI. (1995). Materia Medika Indonesia, Jilid IV. Jakarta: Depkes RI. Hal 308, 310, 313.

Departemen Kesehatan RI. (2000). Parameter Standar Umum Ekstrak Tumbuhan Obat, Cetakan I. Jakarta: Depkes RI. Hal 1, 10-13.

Geissman, T.A. (1962). The Chemistry of Flavonoids Compounds, New York: The Macmillan Company. P. 366.

Harborne, J.B. (1987). Metode Fitokimia, Terjemahan Padamawinata dan Soediro. Bandung. Hal 13, 147.

Hernani, Monoraharjo. (2002). Tanaman Berkhasiat Antioksidan, Cetakan I. Penerbit Penebar Swadaya. Hal. 9-11. http://www.pikiranrakyat.com/cetak/0604/17/cakrawala/penelitian.htm

Safitri, R. (2002). Sayuran dan Buah-buahan Pencegah Penyakit Jantung. Pikiran Rakyat Cyber Media.

Sauriasari. Mengenal dan Menangkal Radikal Bebas, Online 2006. http://www.beritaiptek.com/zberitaberitaiptek-2006-01-22-Mengenal-dan-MenangkalRadikal-Bebas.shtml

Silalahi, J. (2006). Makanan Fungsional, Kanisius. Hal 41$49,54-55$

Sofia, D. Antioksidan dan Radikal Bebas, Online 2002. http://www.chemis-try.org/?sect=artikel\&ext=81 